\title{
Isolation and diagnosis of phytochemicals extracted from pomegranate husks and study of the biological effect of extract (O-Veratramide) as an antimicrobial activity
}

\author{
Alaa G. Al-Hashimia', Sinan J. Abdul-Abbas', Najla Hussen Saper Al Garory', \\ Shaker A. N. AL-Jadaan², H. N. K. Al-Salman² \\ ${ }^{1}$ Department of Food Science and Biotechnology, College of Agriculture University of Basrah, Iraq, \\ ${ }^{2}$ Department of Pharmaceutical Chemistry, College of Pharmacy, University of Basrah, Iraq
}

\begin{abstract}
Context: The biological efficiency of O-veratramide (2,3-dimethoxybenzamide) isolated from pomegranate extract was studied. Extraction of $400 \mathrm{~g}$ of dried pomegranate husks was carried out by Soxhlet, and seven organic compounds were extracted using a mixture of organic solvents. O-veratramide has been deposited and isolated. Several solvents such as methanol, chloroform, ethyl acetate, and hexane have been used. The extraction ratio was higher when using methanol and less in chloroform. Objective: The biological efficacy of O-veratramide was investigated against different types of bacteria by taking the highest concentration of this compound and less concentration of the compound. Materials and Methods: The purpose of the manuscript was to study the inhibitory activity of the bacteria using MacConkey Agar as an agro-medium. O-veratramide showed excellent bioavailability against different types of Gram-negative and positive bacteria. Results: All extracts were analyzed by the GC-Mas technique to identify and distinguish the chemical compounds present in the raw extract in both organic and biological layers. A number of internationally recognized detection methods have been used to detect each type of compound extracted. The spectral analysis of the $\mathrm{O}$-veratramide was studied, and its biological efficacy was studied against Gram-negative and positive bacteria. Conclusions: GC-Mas technique revealed the presence of seven compounds in the pomegranate extract. The same technique has demonstrated the possibility of isolating the O-veratramide using different solvents, its potential for estimation, and the study of its biological effect.
\end{abstract}

Keys words: An antimicrobial activity, phytochemicals O-veratramine, pomegranate husk extract

\section{INTRODUCTION}

$\mathrm{B}$ enzimidazole compounds and their derivatives are compounds that have long been known as antibacterial agents such as hydroxybenzanilides, which has biological activity and a significant effect on a wide range of bacteria. This can be attributed to the presence of the aromatic ring, which has been widely spread due to its various uses as antagonists for bacteria and viruses as well as infections and pain relievers. ${ }^{[1-6]}$

O-veratramide is one of the benzimidazole compounds, a substance that is effective against a number of biological activities due to its selective. O-Veratramide (2,3-dimethoxybenzamide), as powder his other chemical name 2,3-dimethoxybenzamide and has molecular formula C9H11NO3, molecular weight $181.191 \mathrm{~g} / \mathrm{mol}$, has melting point $75-85^{\circ} \mathrm{C}$, his chemical is currently classified as antibacterial and a pesticide. It can be classified as a biochemist for its high toxicity, as shown in Figure 1.

Antibacterial activity is usually increased by increasing the number of amine groups in the solution as the $\mathrm{NH}_{2}$ group

\section{Address for correspondence:}

H. N. K. Al-Salman, Department of Pharmaceutical Chemistry, College of Pharmacy, University of Basrah, Iraq. E-mail: hsennaserh@yahoo.com

Received: $28-11-2018$

Revised: $16-12-2018$

Accepted: 22-12-2018 


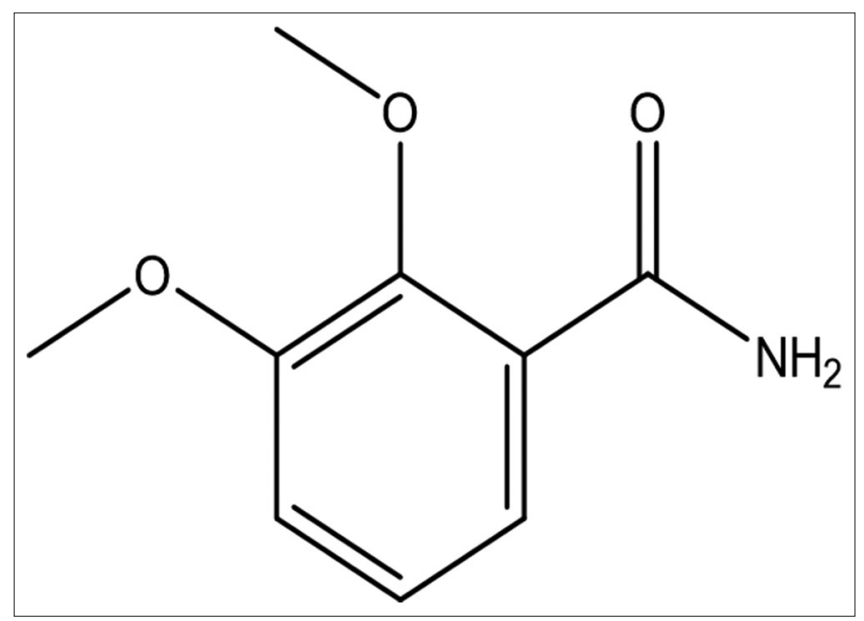

Figure 1: Chemical structure of O-veratramine

enters the chemical composition of O-veratramide. A number of researchers where they mentioned that the presence of amine groups are more effective in the elimination of both positive and negative bacteria. ${ }^{[7-10]}$

The $\mathrm{NH}_{2}$ groups are particularly related to the bacterial surface molecules of the negative charge, which disrupt the bacterial membrane leading to its dissolution and thus cell death. On this basis, the amine groups have attracted high antibacterial efficacy as a new class of antibiotics. ${ }^{[11-13]}$

In 2011, the world Ozkay et al. chose a series of 14 compounds of benzimidazole compounds for the purpose of testing their susceptibility to a wide range of bacteria. The results showed a clear effect on the bacteria under examination, especially colon bacteria. This was confirmed by a number of tests of some benzimidazole derivatives used for various types of bacteria such as Candida albicans, Staphylococcus aureus, and Yeast Saccharomyces cerevisiae .[14-18]

Inanotherstudyby researchers using 2,3-dimethoxybenzamide on a wide range of bacteria, it was observed that it had a inhibitory effect on the formation of whiteboards when added $3 \mathrm{~h}$ before the vegetative growth but had a less inhibitory effect after adding the end of the vegetative growth and there are some strains which showed a clear effect regardless of the time to add the compound. ${ }^{[19-23]}$

Zhang et al. ${ }^{[24]}$ said that, for the purpose of obtaining the inhibitory effect against bacteria, the structural properties of benzimidazole should be improved by adding a series of alkyls of different lengths that would increase the efficiency of the compound against the bacteria by binding the gasoline group to another group containing nitrogen. An increase in the double electrons, which the source of nitrogen, is one of the important factors to reach the optimum value to reduce bacterial activity as it is known that the high density of electrons cause a significant loss of activity of bacteria as well as the presence of ammonia in the Benzimidazole structure raises the permeability of the cell membrane and thus the cell is susceptible to degradation and the permeability of the intracellular components and their death. ${ }^{[25-30]}$

\section{MATERIALS AND METHODS}

All solvents and reagents were of analytical grade unless indicated otherwise, and all experiments were performed with deionized water $(18.2 \Omega-\mathrm{cm})$ resistivity at $25^{\circ} \mathrm{C} .^{[31]}$

\section{Chemical and Biological Materials}

- Hexane for high-performance liquid chromatography (HPLC) grade, BDH Chem. Ltd.

- $\quad$ Ethyl acetate, BDH Chem. Ltd.

- $\quad$ Ethanol and methanol, BDH Chem. Ltd.

- Chloroform for HPLC Grade Ltd.

- Water was obtained by following purification in a deionized water system.

- Nutrient Agar, Bio-Pharm. Tech.

- MacConkey Agar, Bio-Pharm. Tech.

\section{Collection of Materials}

Pomegranate husk materials were collected of ripe pomegranate fruits and washed from the soil with water. The crusts were then separated from the rest of the fruit. The crusts were placed on large filtration papers at room temperature. The crust was dried and grinded in a small electric mill. After that the dry powder was obtained, until they are used. ${ }^{[32,33]}$

\section{Extraction}

\section{Preparation of pomegranate husk extracts}

The method described globally was adopted by dissolving $400 \mathrm{~g}$ of pomegranate husk powder in $1 \mathrm{~L}$ of water. It was mixed well with an electric mixer and then placed in a trembled incubator at $25^{\circ} \mathrm{C}$ for $24 \mathrm{~h}$ to increase the extraction ratio. When the filtrate was collected and concentrated in the rotary vacuum evaporator at a temperature of $40^{\circ} \mathrm{C}$, the concentrated extract was placed in dishes with a large surface area. The remaining water was dried in an electric oven at a temperature of $40^{\circ} \mathrm{C}$ until the water completely evaporated and obtained dry powder. The powder was placed in tightly sealed containers and marked with PVC and frozen under the $4^{\circ} \mathrm{C}$ until to use. ${ }^{[34-36]}$

\section{Extraction Methods}

The method of extracting all active compounds from pomegranate husks was completed in two main steps by the separatory funnel; the first step was completed by mix solvent ethanol:chloroform:water (40:40:10). A number of organic compounds were obtained from the extraction process 
from the organic and the aquatic layer, three compounds which were obtained in the organic layer are 1-docosene, 2-piperidinone, N-[4-bromo-n-butyl]-, and eicosane and four compounds from the aquatic layer are tributyl acetyl citrate (TBAC), O-veratramide, methyl palmitate (MP), and butanamide, N-decyl-N-methyl-.

\section{Phytochemical Screening of Pomegranate Husk Extract}

The $\mathrm{pH}$ value of the pomegranate husk extract was determined by mixing $10 \mathrm{~g}$ of dried powder with $50 \mathrm{ml}$ of distilled water, and then, the solution was filtered. The $\mathrm{pH}$ was measured by $\mathrm{pH}$-meter. After that, some qualitative chemical tests were conducted to determine some of the aggregates and active ingredients.

Alkene (1-decosene) has been detected using nitrous reagent, and this reagent was similar to reagent 2-piperidinone, N-[4bromo-n-butyl]-. 1-decosene was measured in the wavelength $260 \mathrm{~nm}$ with ultraviolet (UV)-vis spectrophotometer versus the blank. Alkane (eicosane) was measured using doublebeam UV-vis with fixed wavelength $375 \mathrm{~nm}$. The polyhydric compound (TBAC) that have multi hydroxid groups with the standard reagent in the wavelength $410 \mathrm{~nm}$ was measured using double-beam for UV-Vis against blank. The aromatic (hydroxy-carbamide O-veratamide) was measured at $230 \mathrm{~nm}$. Fatty acid (MP) was measured in $310 \mathrm{~nm}$. The aliphatic amide (butanamide, N-decyl-N-methyl-) was measured in the wavelength $210 \mathrm{~nm}$ with UV-vis spectrophotometer. All the maximum wavelengths that have been determined for all active compounds after scanning are measured by the same UV spectrum device - which contains a dual-beam package.

\section{Isolation and Purification of O-Veratramide (2,3-Dimethoxymethybenzamide)}

After isolating the two layers, organic and aquatic from each other, an isolation was done for the compound O-veratramide (2,3-dimethoxybenzamide) from the aquatic layer, being the compound to be studied biologically against different types of agricultural pests. A special method was used to isolate and purify the $\mathrm{O}$-veratramide from the aquatic layer containing this compound using different solvents such as methanol, chloroform, ethyl acetate and hexane, each solvent used separately to precipitation, analyze and estimate the compound.

\section{Chemical Detection Results}

Chemical detection results indicated seven active compounds in the organic layer and aquatic layer extracted from pomegranate husks. Four extracts from the aquatic layer are TBAC, O-veratramide, MP, and butanamide, N-decylN-methyl and three organic extracts are 1-docosene, 2-piperidinone, N-[4-bromo-n-butyl]-, and ecosane. The results obtained were confirmed by GC-Mas technique (GCMS) and UV diagnostic results.

\section{Determination of O-veratamide (2,3-Dimethoxybenzamide)}

Using a standard solution of O-veratamide, direct measurements were made for plant extracts in volume $(1.0 \mathrm{~mL})$ for different concentrations $(0.1,0.2,0.3,0.4$, and 0.5$) \mu \mathrm{g} / \mathrm{ml}$. O-veratamide absorption was measured at a wavelength of $230 \mathrm{~nm}$. The maximum wavelength is determined after scanning with the same UV device against deionized water as blank. The concentration of O-veratamide was calculated from $\mathrm{R}^{2}$ values obtained from the linear regression equation obtained from Quercetin calibration. TPCs were determined using linear regression equation; the standard chart of $\mathrm{O}$-vertamide was obtained. The concentration of O-vertamide extract was calculated after purification. The mean $\operatorname{SD}(n=3)$ was expressed a $\mathrm{mg} / \mathrm{g}$ from $\mathrm{O}$-vertamide equivalent from dry extract. The chemical composition of $\mathrm{O}$-vertamide is not currently accurately classified in our databases, nor has information about this compound been identified including synonyms, ID numbers, and we do not have complete information about this chemical. The molecular mass in the GC-Mass measurements does not specifically refer to the O-vertamide structure due to the interaction of this compound with fragments generated by cracking the same mass formed due to the very high temperature of the GC-Mass. Therefore, the parent mass is shown at 281 .

\section{Determination of 1-docosene}

Nitrous reagent was used to determine the 1-docosene in the various organic crude extracts. 1-docosene standard was used as a reference standard (10-50 $\mu \mathrm{g} / \mathrm{mL})$ for plotting calibration curve $\mathrm{R}^{2}$. A volume of $1.0 \mathrm{~mL}$ from the plant extract $(50 \mu \mathrm{g} / \mathrm{mL})$ was mixed with $1.0 \mathrm{~mL}$ of nitrous reagent (diluted 1:10 with deionized water) and was neutralized with $3 \mathrm{~mL}$ of $\mathrm{HNO}_{3}$ acid $(1 \% \mathrm{w} / \mathrm{v})+$ two drops from $\mathrm{Br}^{2}$ solution. The reaction mixture was kept in the dark at room temperature for $1 \mathrm{~h}$ with intermittent shaking. The absorbance of the resulting nutty dark color was measured using doublebeam UV-visible spectrophotometer at a fixed wavelength of $254 \mathrm{~nm}$. The TPCs were determined using linear regression equation obtained from the standard plot of 1-docosene, and this compound was calculated in mean $\mathrm{SD}(n=3)$ and expressed as mg/g 1-docosene equivalent of the dry extract.

\section{A Similar Identification of Amide 2-Piperidinone, $\mathrm{N}$-[4-Bromo-n-Butyl]-}

By a standard solution of 2-bisperididone, N-[4-bromon-butyl], the plant extract was direct measured in volume $1.0 \mathrm{~mL}$ and different concentrations $(2.0,4.0,6.0,8.0$, and $10.0 \mu \mathrm{g} / \mathrm{ml}$ ). The 2-piperidinone compound, N-[4-bromo-nbutyl]- was estimated at a peak absorption of $260 \mathrm{~nm}$ with 
UV spectrometer against the deionized water as blank. The amount of 2-piperidinone, N-[4-bromo-n-butyl] was calculated from the linear regression equation obtained from Quercetin calibrations. TPCs were determined using the linear regression equation obtained from the standard plot of 2-piperidinone, N- [4-bromo-n-butyl]. This compound was calculated as mean $\mathrm{SD}(n=3)$ and was expressed in $\mathrm{mg} / \mathrm{g}$ from 2-piperidinone, $\mathrm{N}$ - [4-bromo-n-butyl]- equivalent of the dry extract.

\section{Determination of Eicosane}

Nitrous reagent was used to determine the Eicosane various from organic crude extracts. A pure powder from eicosane was used as a reference standard at concentration range (10-50 $\mu \mathrm{g} / \mathrm{mL}$ ) for plotting calibration curve. A volume of $1.0 \mathrm{~mL}$ of the plant extract $(50 \mu \mathrm{g} / \mathrm{mL})$ was mixed with $1.0 \mathrm{~mL}$ of nitrous reagent (diluted 1:10 with deionized water and was neutralized with $3 \mathrm{~mL}$ of $\mathrm{HNO}_{3}(1 \% \mathrm{w} / \mathrm{v})$ without bromination. The reaction mixture was kept in the dark at room temperature for $1 \mathrm{~h}$ with intermittent shaking. The absorbance of the resulting light yellow color was measured using double-beam UV-Vis spectrophotometer that is fixed wavelength $375 \mathrm{~nm}$. The TPCs were determined using linear regression equation obtained from the standard plot for eicosane. This compound was calculated as mean SD $(n=$ 3 ) and expressed as $\mathrm{mg} / \mathrm{g}$ eicosane equivalent of dry extract.

\section{Determination of TBAC}

TBAC in crude extracts was determined by the reported procedure. The plant extracts were used to find a standard calibration curve. Briefly, $10 \mathrm{mg}$ of plant extracts were dissolved in $80 \%$ ethanol and then diluted to $10,20,30,40$, and $50 \mu \mathrm{g} / \mathrm{mL}$. The diluted standard solutions of plant extracts in volume $1.0 \mathrm{~mL}$ for different concentrations were separately mixed with $1.0 \mathrm{ml}$ of $99 \%$ ethanol, $0.1 \mathrm{~mL}$ of $10 \%$ aluminum chloride, $0.1 \mathrm{~mL}$ of $1 \mathrm{~mol} / \mathrm{L}$ potassium acetate, and $3.0 \mathrm{~mL}$ of deionized water in a test tube. The test tubes were incubated for $1 \mathrm{~h}$ at room temperature to complete the reaction. The reaction mixture was measured in the wavelength $410 \mathrm{~nm}$ with double-beam UV-visible against blank. A typical blank solution contained all reagents except ferric chloride which is replaced by the same amount of deionized water. The amount of TBAC was calculated from linear regression equation obtained from the extract plant calibration. The TPCs were determined using linear regression equation obtained from the standard plot of TBAC. This compound was calculated as mean $\mathrm{SD}(n=3)$ and expressed as $\mathrm{mg} / \mathrm{g}$ for TBAC equivalent of dry extract.

\section{Estimation of MP}

Using the standard solution of MP, the direct measurement of the plant extract $(1.0 \mathrm{ml})$ was measured for different concentrations $(5,10,15,20$, and $25 \mu \mathrm{g} / \mathrm{mL})$. The absorbance of the MP compound was measured at the maximum wavelength $310 \mathrm{~nm}$ determined after scanning in the same apparatus that has double-beam versus the deionized water as blank. The amount of MP was calculated from the linear regression equation obtained from the calibration curve. TPCs were determined using the linear equation obtained from the standard scheme of MP. SD was calculated for MP $(n=3)$ and expressed as $\mathrm{mg} / \mathrm{g}$ for the dry extract.

\section{Determination of Butanamide, N-Decyl-N-Methyl-}

Using the standard solution of butanamide, N-decyl-Nmethyl, direct measurement of plant extracts $(1.0 \mathrm{ml})$ at a different concentration $(1,2,3,4$, and $5 \mu \mathrm{g} / \mathrm{ml})$ of $0.1 \mathrm{ml}$ sample. The uptake of butane-N-decyl-N-methyl-compound was measured at the maximum wavelength of $210 \mathrm{~nm}$ specified after scanning in the same device containing a double pack versus deionized water as empty. The amount of butanamide, N-decyl-N-methyl was calculated from the linear regression equation obtained from the calibration curve. TPCs were determined using the linear equation obtained from the standard plan of butanamide, N-decyl$\mathrm{N}$-methyl. SD was calculated for butanamide, N-decyl-Nmethyl $(n=3)$ and expressed as $\mathrm{mg} / \mathrm{g}$ for the dry extract.

\section{GC-Mass Analysis}

In general, studies indicate that all extracting compounds can be analyzed more precisely by applying GC-MS (mass chromatography, MSDCHEM \1 \ METHODS । MUAFAQ.M) to determine negative M/Z. Fragments allow easy identification of composite parts by mass spectrum. To shorten the total time for GC analysis of these compounds, the cavity column should be long and narrow as $10 \mathrm{~m} \times 0.250$ I.m, I.D, $0.25 \mu \mathrm{m}$, SS., Inlet He and recommended optimal conditions for separation and diagnosis of all extraction compounds as listed in Table 1.

\section{Chemical Composition of Extracts by GC-MS Analysis}

The compounds were studied through GC-mass [Table 1 and Figures 2-4] to create a molecular ion for each extract. It has been found that its molecular ion equals the weight of the formula of the minus one or more. The graphs confirm the weight of all compound molecules that give a good indication of the isolation and identification of all chemical compounds extracted separately.

\section{Data Analysis}

Data analysis is expressed as mean $\pm \mathrm{SD}$. (t) was tested for ANOVA and was used to analyze the level of statistical significance between groups. $P<0.05$ was considered to be statistically significant. 
Table 1: Data analysis parameters for separation and specific determination of pomegranate husks extract in GC-Mass spectrum

Column

HP-5MS, 5\% phenyl methyl Sillox (1629.5)

$30 \mathrm{~m} \times 0.250 \mu \mathrm{m}$ I.D. $\times 0.25 \mu \mathrm{m}$, SS., Inlet He

EMV mode

Resulting EM voltage

Low mass

High mass

Threshold

Minimum quality for all narcotics

Flow rate

Run time

Hold up time

Solvent delay

Average velocity

Temperature

Pressure

GC: Gas chromatography
Gain factor (1.00)

1306

28

441

150

$(90-97 \%)$

$1 \mathrm{ml} / \mathrm{min}$

$24 \mathrm{~min}$

$1.5388 \mathrm{~min}$

$3.00 \mathrm{~min}$

$36.796 \mathrm{~cm} / \mathrm{s}$

Initial $70^{\circ} \mathrm{C}$ to maximum $375^{\circ} \mathrm{C}$

8.81 Psi

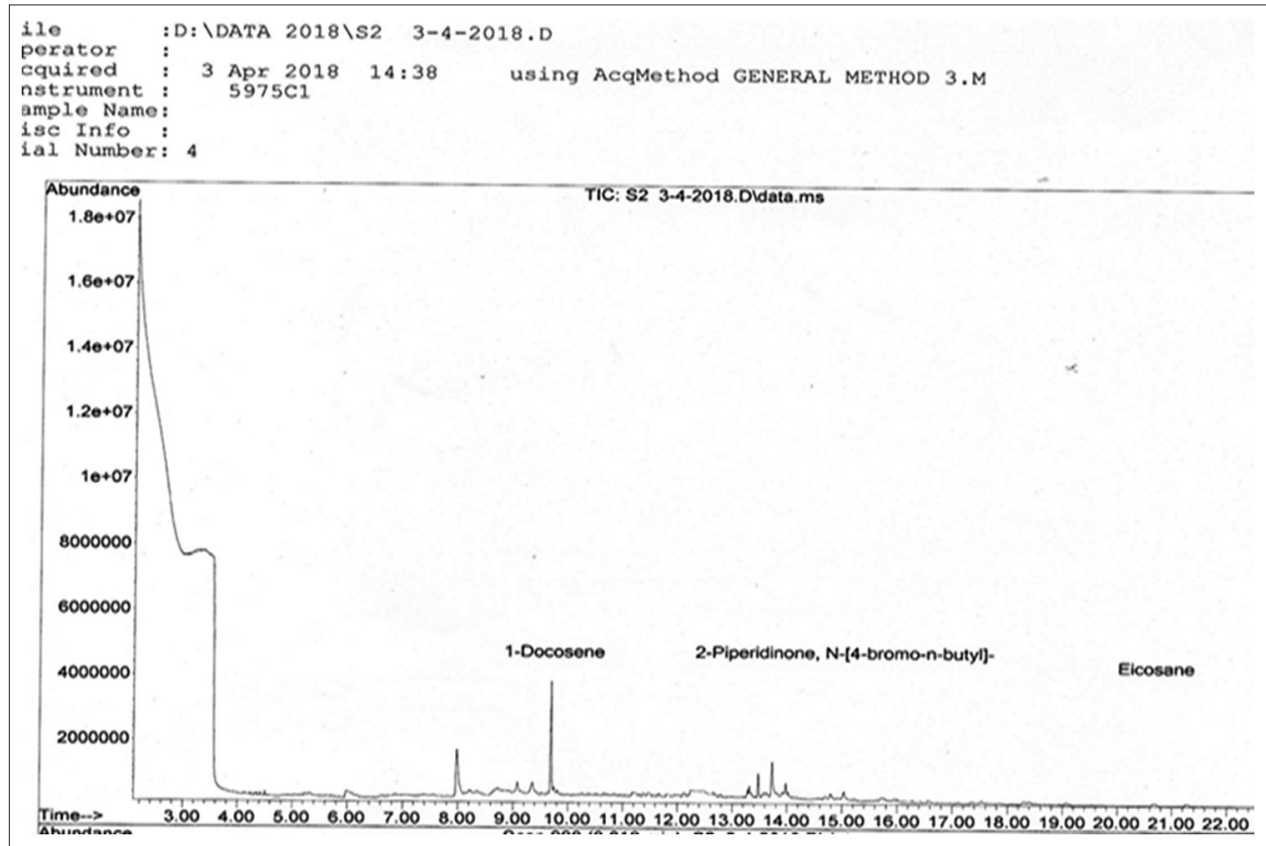

Figure 2a: Gas chromatography-mass spectrum for three compounds in organic layer

\section{Miscellaneous Extraction Compounds}

A number of biologically active compounds were obtained from the organic and aquatic layers in the pomegranate extract as shown in Table 2 and Figure 2. The process was performed using different solvents. Active extract O-veratramide was obtained with high bioefficacy against some types of bacteria. ${ }^{[37,38]}$

\section{Percentage obtained from extracts}

Approximately $20 \mathrm{~g}(5 \%)$ dry mass of all extract components was obtained from extracting $400 \mathrm{~g}$ of pomegranate husks after $16 \mathrm{~h}$ of continuous hot extraction in Soxhlet extract using ethanol solvent. The Copshan division method was used for raw alcohol extracts. Table 3 shows the different extraction ratios when using different solvents such as hexane, chloroform, ethyl acetate, and methanol.

\section{O-vertamide Crude}

The weight ratio of $\mathrm{O}$-vertamide is calculated using the following linear regression equation obtained from the standard O-vertamide. 


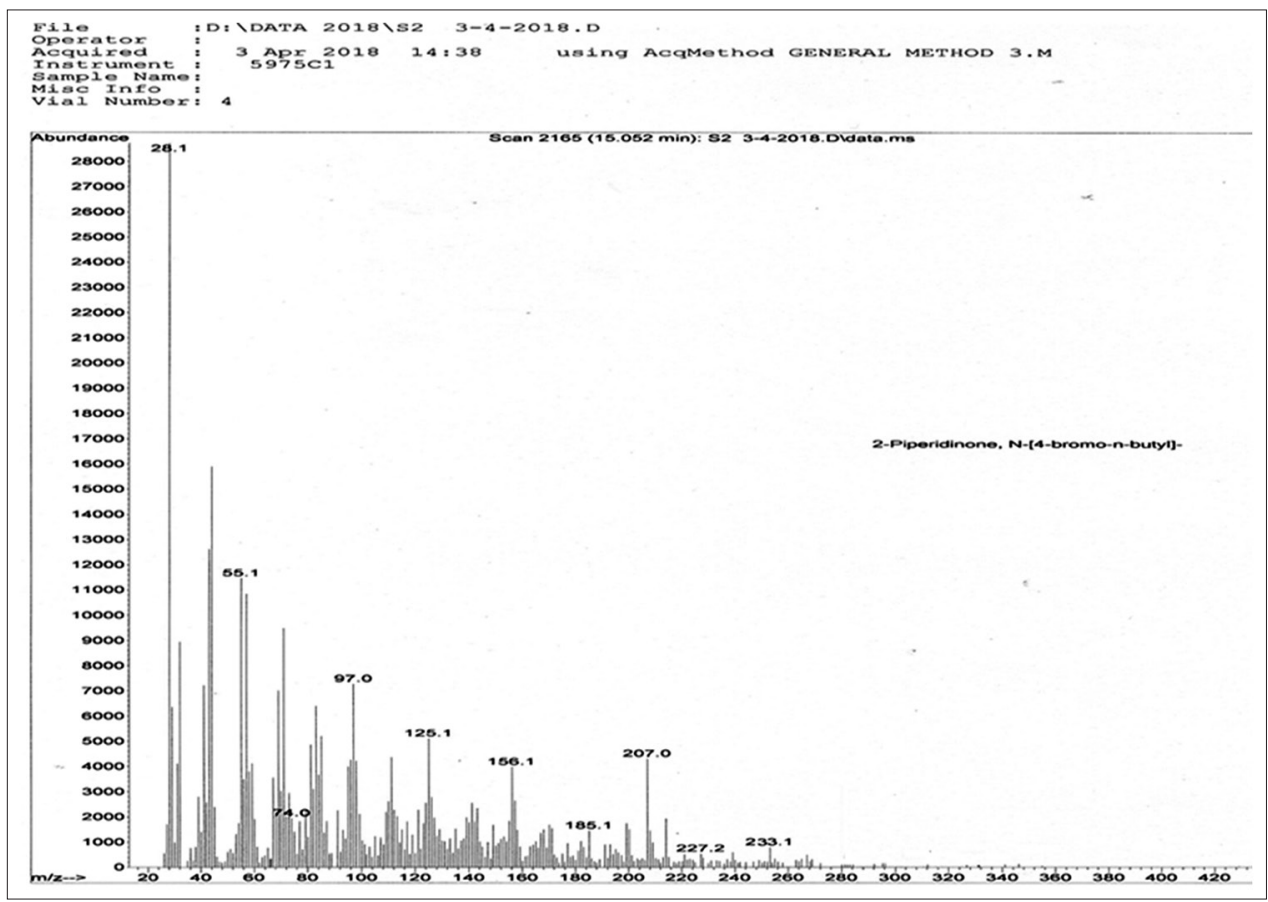

Figure 2b: mass spectrum for 2-piperidinone, N-[4-bromo-n-butyl]

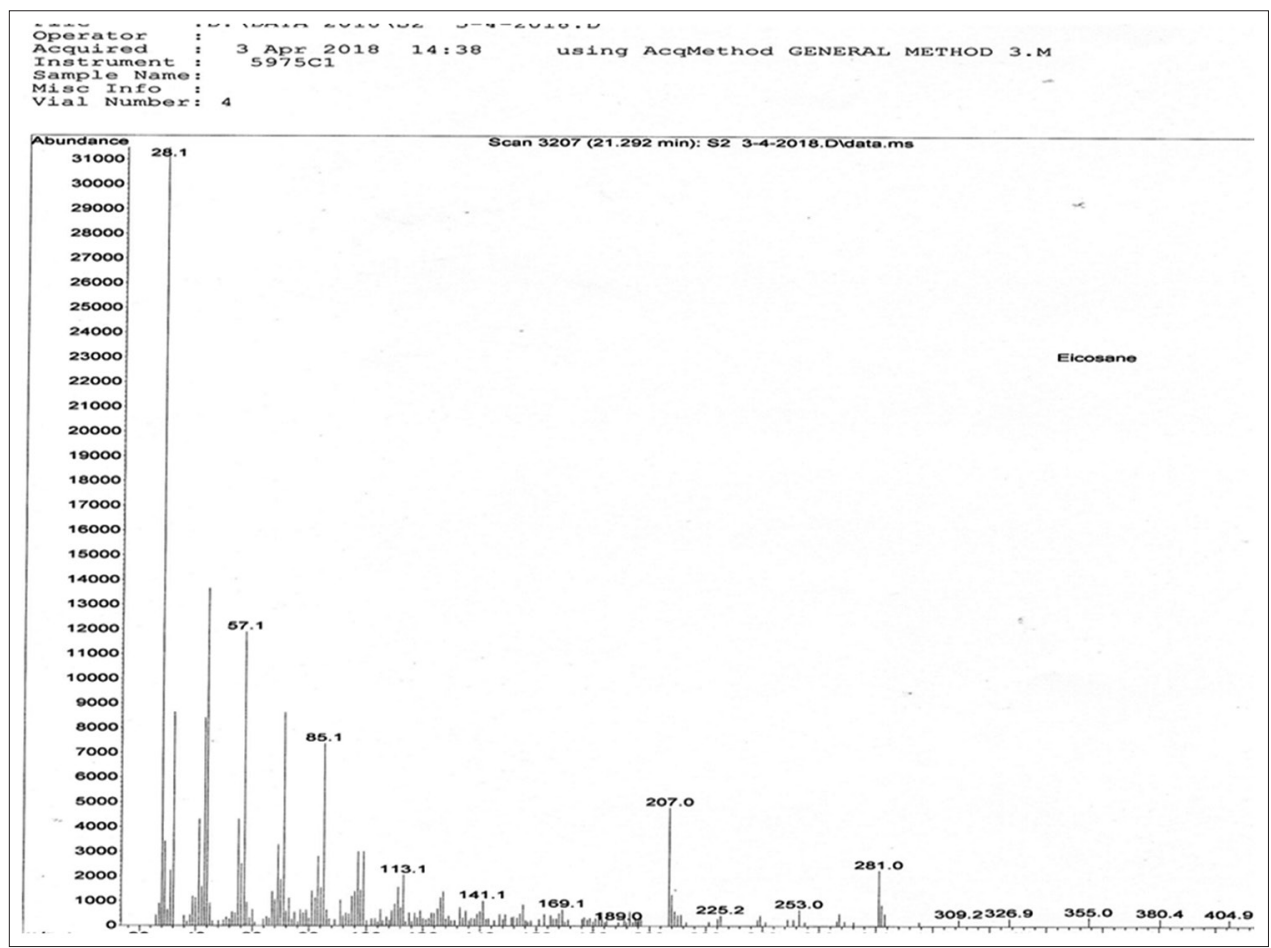

Figure 2c: mass spectrum for eicosane

\begin{tabular}{|c|c|c|c|c|c|c|c|}
\hline Phase & 1-Docosene & $\begin{array}{c}\text { 2-piperidinone, } \\
\text { N-[4-bromo-n-butyl]- }\end{array}$ & Eicosane & TBAC & O-Vertamide & MP & $\begin{array}{c}\text { Butanamide, } \\
\mathrm{N}-\text { decyl-N-methyl- }\end{array}$ \\
\hline Organic layer & + & + & + & - & - & - & - \\
\hline Aquatic layer & - & - & - & + & + & + & + \\
\hline
\end{tabular}

TBAC: Tributyl acetyl citrate, MP: Methyl palmitate 


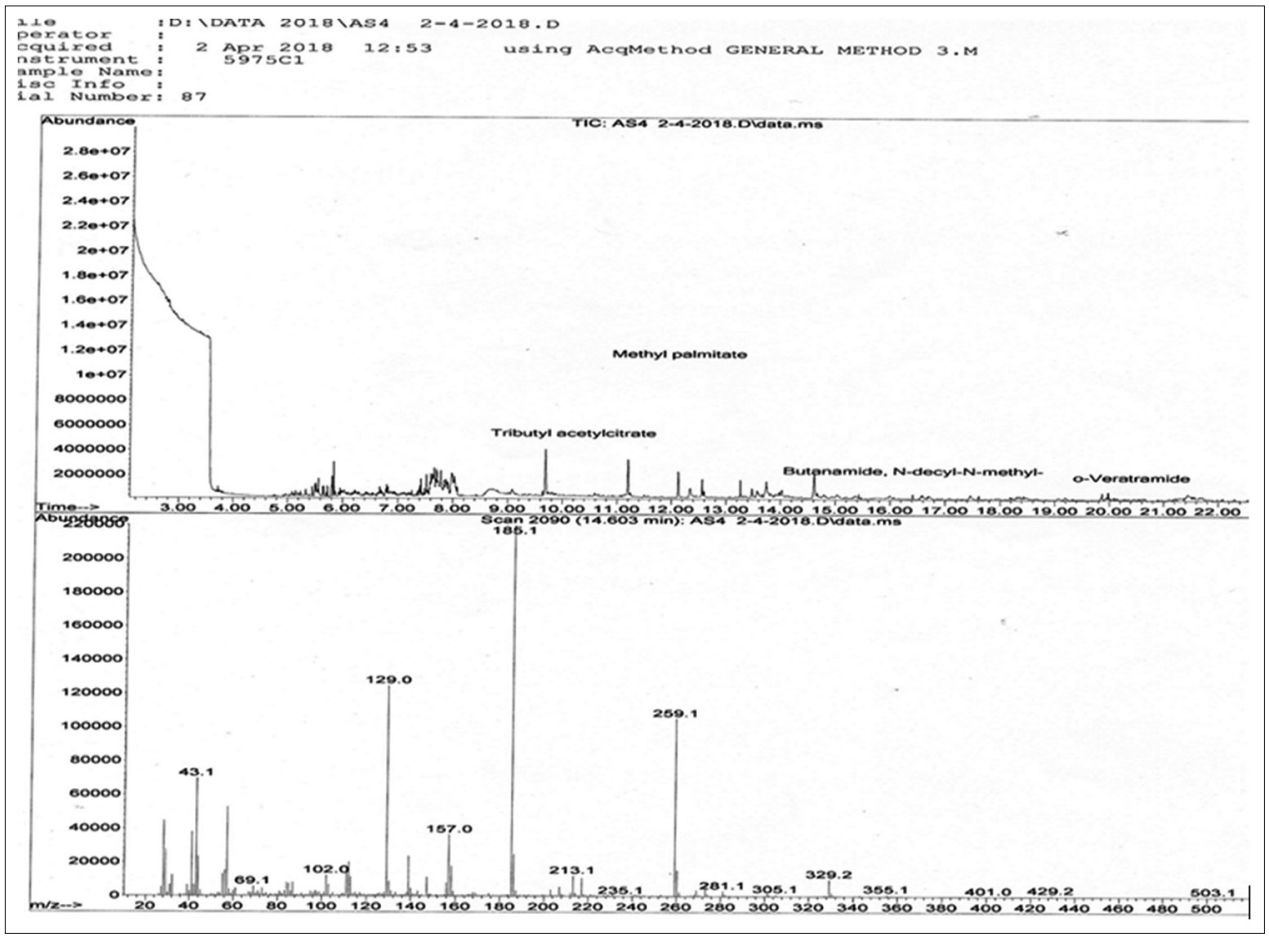

Figure 3: GC-mass spectrum for four compound in aqua layer,

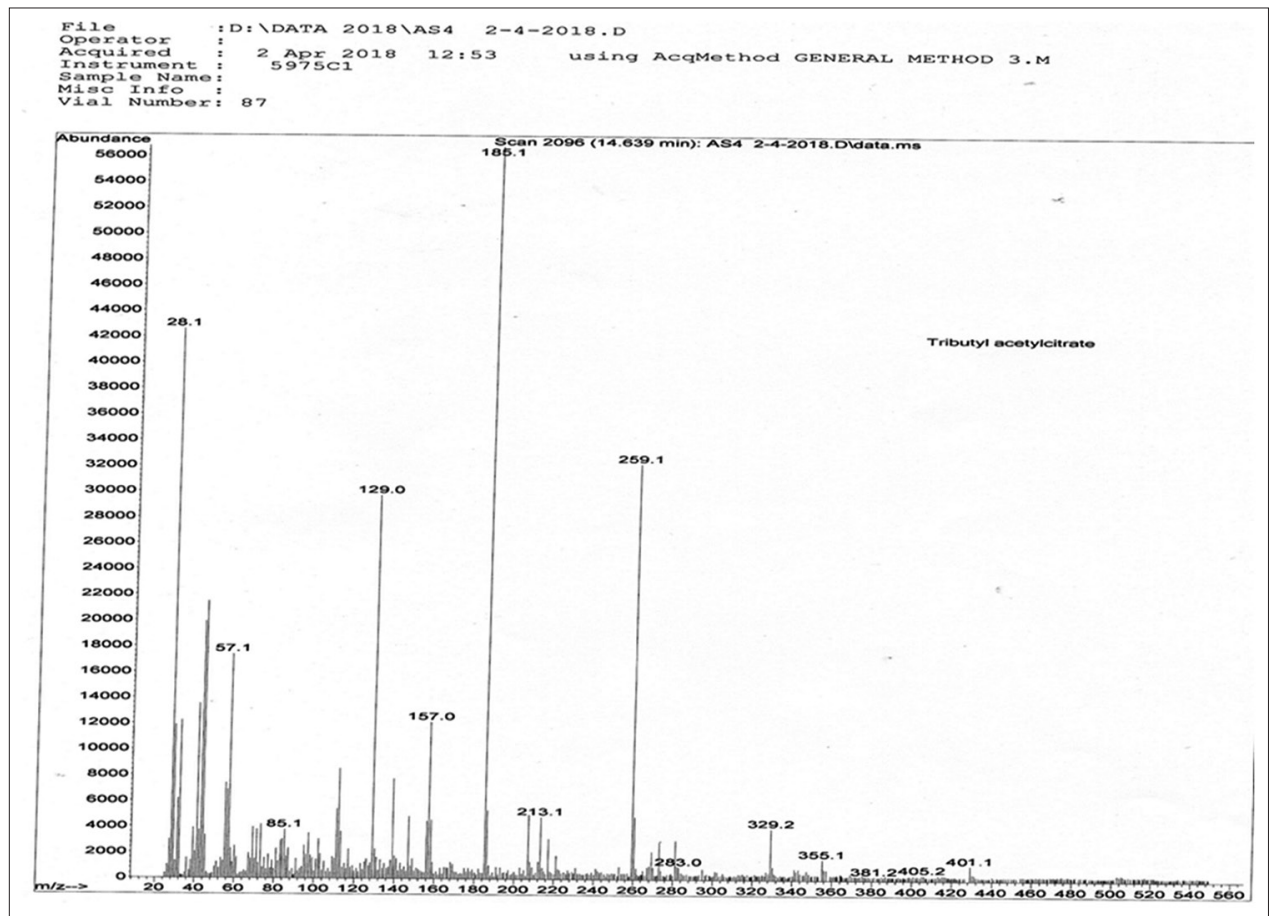

Figure 3a: mass spectrum for tri-butyl acetyl citrate

$$
y=0.012 x+0.030, R^{2}=0.9988
$$

Where $\mathrm{y}$ is absorbance and $\mathrm{x}$ is the amount of O-vertamide that calculated by the microgram unit.

The crude extract of O-vertamide in methanol, chloroform, ethyl acetate, and hexane was $89 \pm 0.5,71.18 \pm 1.65,95.12$ \pm 0.30 , and $80.28 \pm 0.13$, respectively, and the statistical significance was calculated for all values of the obtained results $(P=0.001)$.

Ethyl acetate extract was found to contain the highest amount of O-vertamide compound followed by methanol, hexane, and chloroform. However, little quantity O-vertamide compounds were detected in chloroform extract. A significant difference 


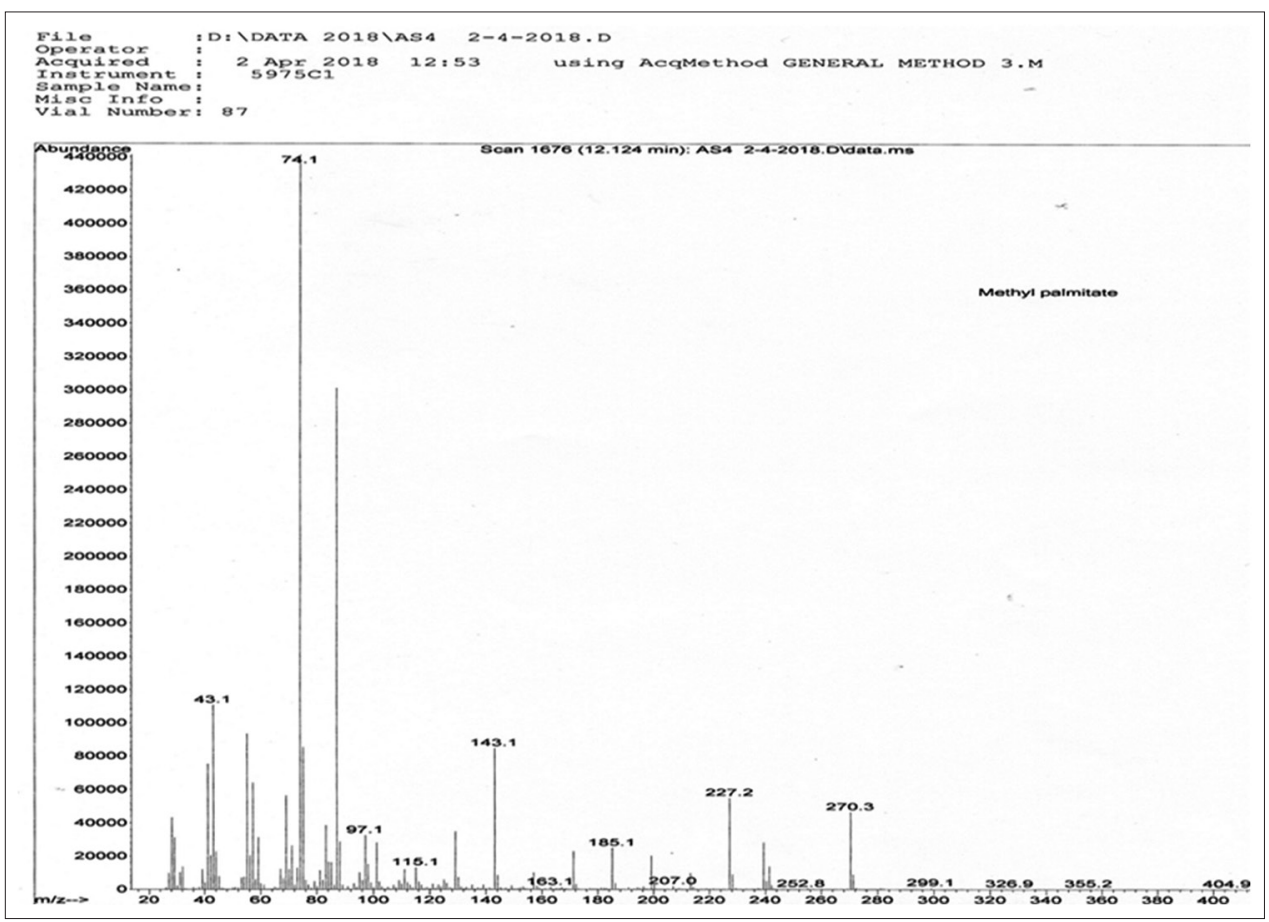

Figure 3b: mass spectrum for methyl palmitate

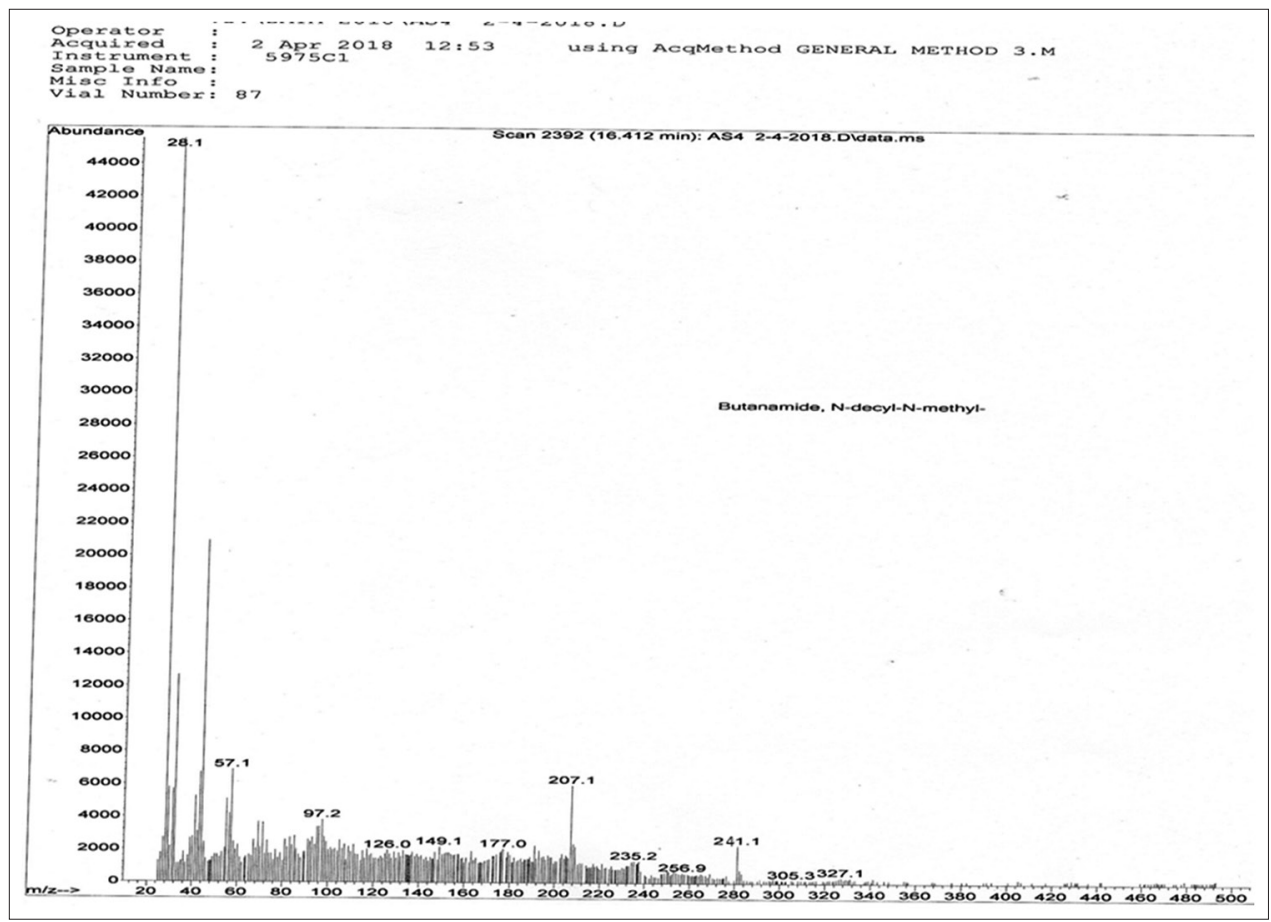

Figure 3c: mass spectrum for butanamide, $\mathrm{N}$-decyl-N-methyl

\begin{tabular}{|c|c|c|}
\hline Extract & Amount (g) & Yield (w/w) \% \\
\hline Methanol & 7.8 & 39 \\
\hline Chloroform & 1.1 & 5.5 \\
\hline Ethyl acetate & 7.1 & 35.5 \\
\hline Hexane & 4 & 20 \\
\hline
\end{tabular}

in the aquatic layer contents for different extractions was observed by the ANOVA parameter test.

\section{Determination of Antimicrobial Activity}

Thesusceptibilityofthecompound(2,3-dimethoxybenzamide) was tested on four types of common bacteria associated with food S. aureus, Pseudomonas aeruginosa, Escherichia 


\section{Al-Hashimia, et al.: An antimicrobial activity}

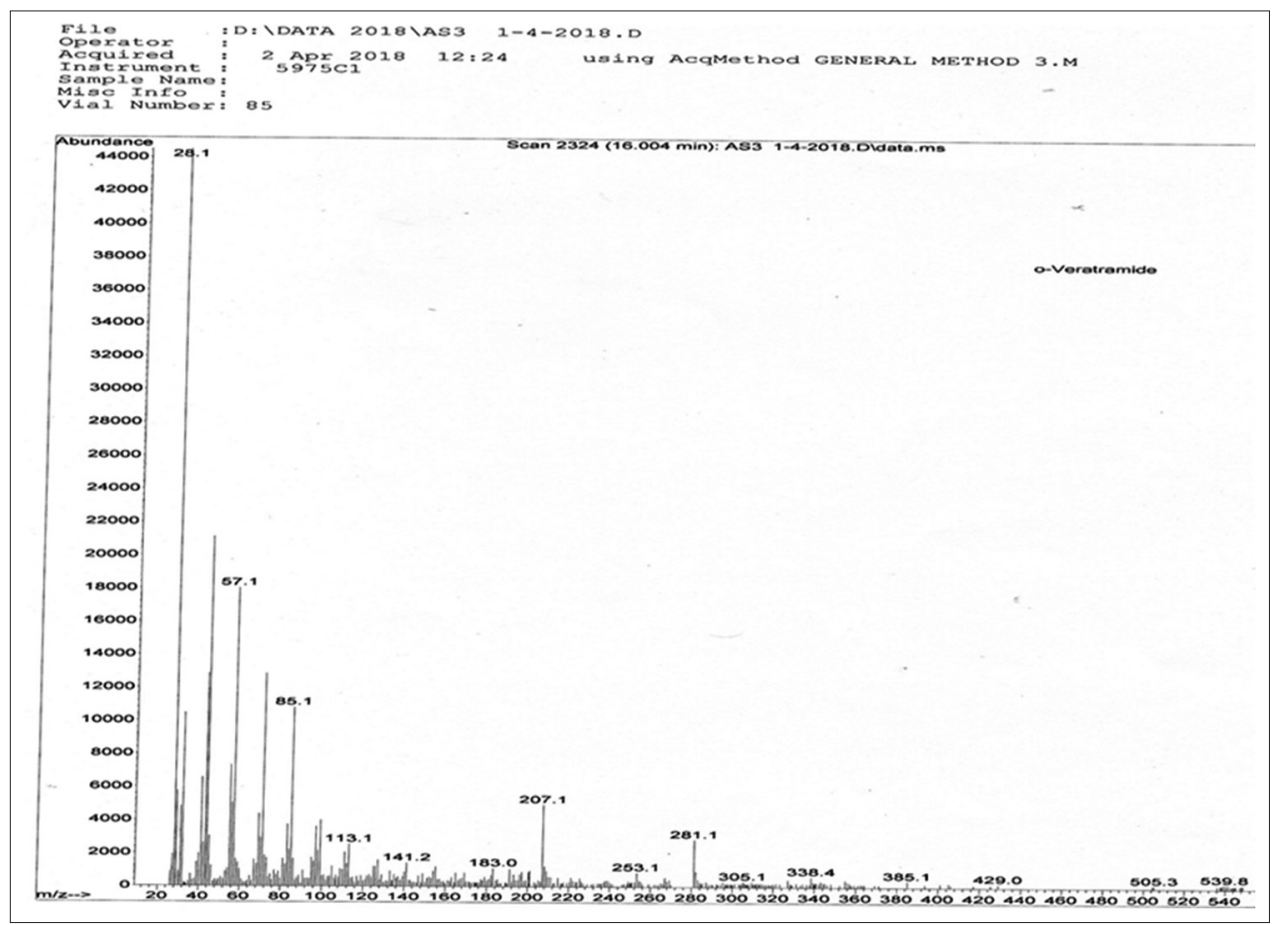

Figure 3d: mass spectrum for O-veratramide (2,3-dimethoxymethybenzamide)

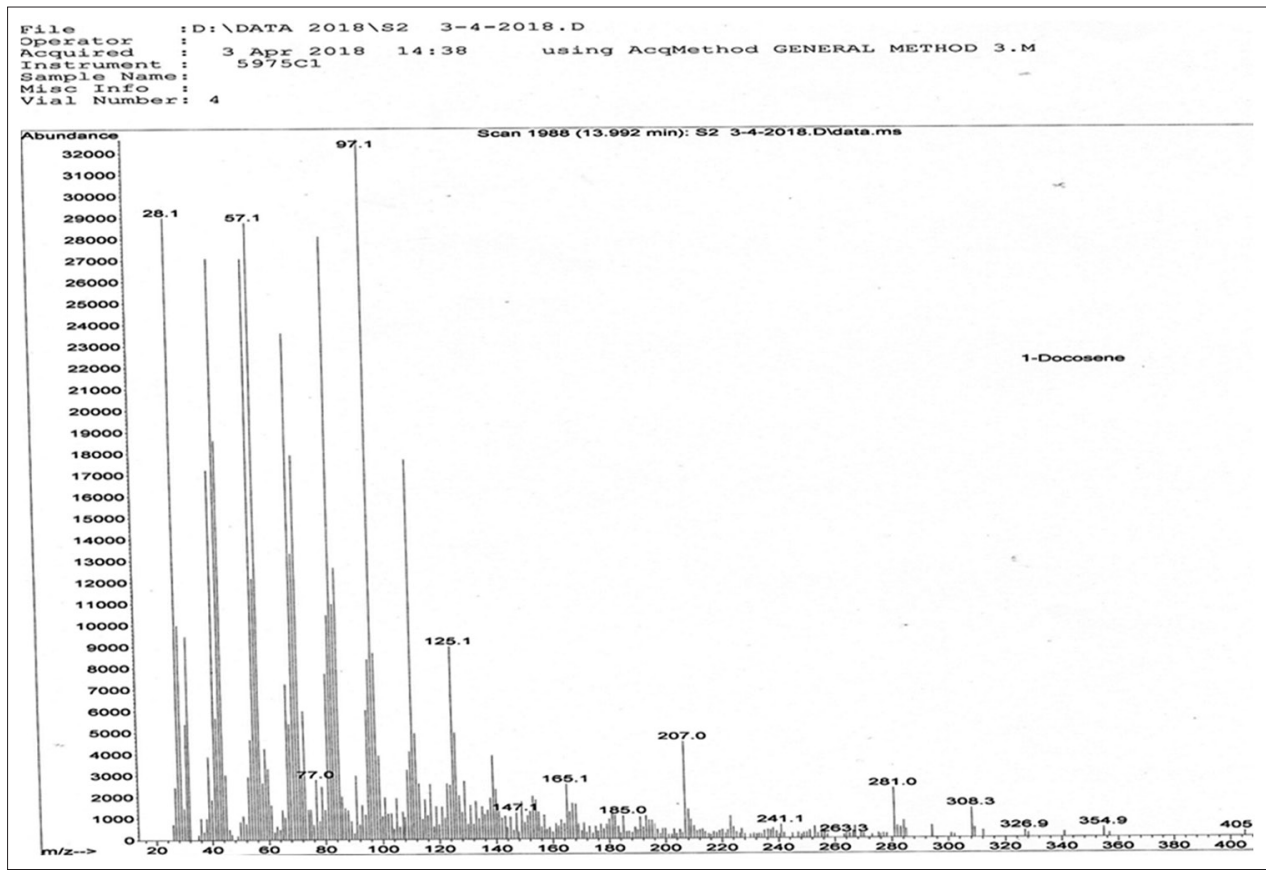

Figure 4: (a) Mass spectrum for 1-docosene

coli, and Klebsiella pneumonia. Four types of bacterial species are used for these studies; the ATCC number of species is as follows: $S$. aureus (ATCC 25923), $P$. aeruginosa (ATCC 27853), K. pneumonia (ATCC 13882), and E. coli (ATCC25922). The activated bacteria were suspended according to the method described by Jianu et al., (106 cells $/ \mathrm{ml})$ and using the method of dissemination $(10 \mu \mathrm{g} / \mathrm{disk})$, the incubation of the dishes was carried out for $24 \mathrm{~h}$ at a temperature of $10 \mu \mathrm{g} / 37^{\circ} \mathrm{C}$, after incubation, the diameter of the inhibition area was measured in millimeters of bacterial strains, and the test was performed on three replicates. ${ }^{[39,40]}$ 


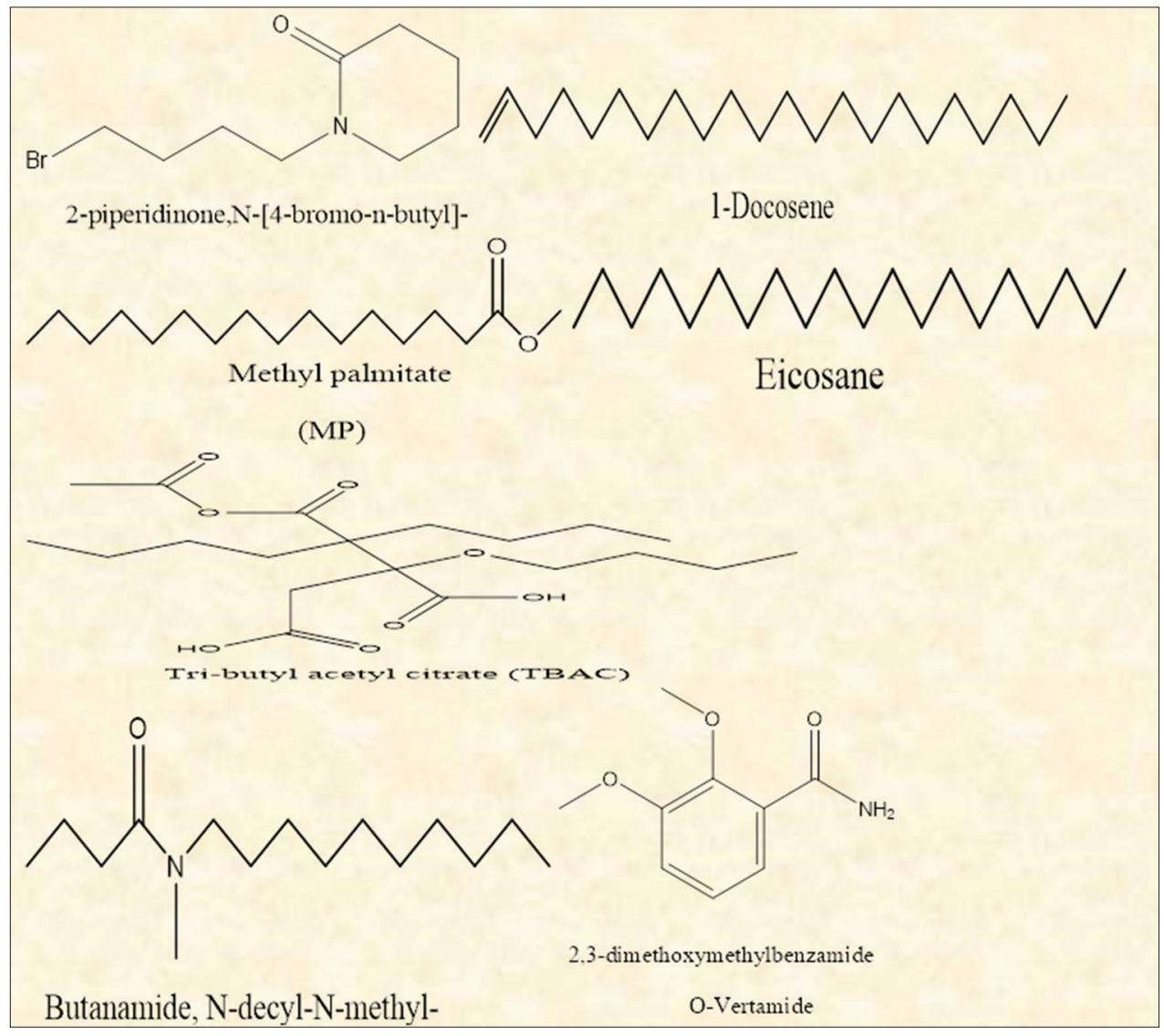

Figure 4: (b) compounds obtained from the organic and aquatic layers

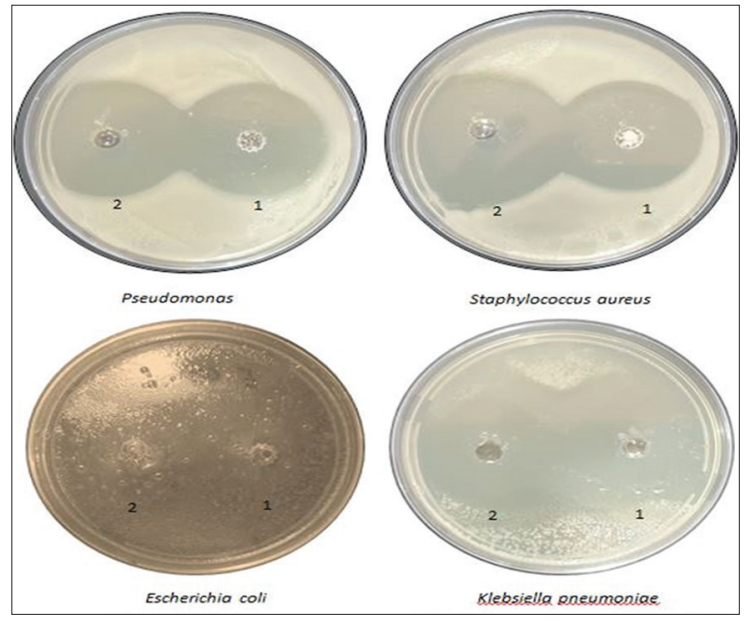

Figure 5: The results of the antibacterial examination (Staphylococcus aureus, Pseudomonas aeruginosa, Klebsiella pneumonia, and Escherichia coli)

\section{RESULTS AND DISCUSSION}

Figure 5 shows the results of the antibiotic test ( $S$. aureus, $P$. aeruginosa, K. pneumonia, and E. coli) using concentrations of 2,3-dimethoxybenzamide (10 $\mu 1$ and $15 \mu 1)$ referred to 1 and 2 , respectively, and it is noted that the highest inhibition of the compound was on the K. pneumonia bacteria to form a large area of the dish followed by S. aureus, which the area of inhibition of the sample (concentration 1) by $27 \mathrm{~mm}$, while the diameter of inhibition of the sample (concentration 2) of the same bacteria diameter of $34 \mathrm{~mm}$ higher, the amount of inhibition. For Pseudomonas, it was observed that they were close to the concentration ( 1 and 2) by $28 \mathrm{~mm}$ and $30 \mathrm{~mm}$ respectively, while the effect of inhibition of the compound for both concentrations on E.coli with concentration (1 and 2) was $12 \mathrm{~mm}$ and $17 \mathrm{~mm}$ respectively compared with other types of bacteria under study. Other bacteria were studied with an inhibition of concentrations (1 and 2) which was $12 \mathrm{~mm}$ and $17 \mathrm{~mm}$, respectively. ${ }^{[3,41-44]}$

\section{CONCLUSIONS}

In this study, seven active compounds were extracted and isolated in pomegranate extract. Their chemical composition was determined by GC-MS, one of the compound as O-veratramide used against different types of Gram-positive and Gram-negative bacteria. The presence of biologically active compounds in pomegranate husks demonstrated the importance of pharmacy. However, more studies will be required to find its biological activity and biological character. 


\section{ACKNOWLEDGMENTS}

The student would like to thank all Professors in Discussion Committee and thank the staff of the Food Science and Biotechnology Laboratories in the College of Agriculture, University of Basrah. Authors also give thanks and appreciation to the supervisor of working and writing this humble Research.

\section{CONFLICTS OF INTEREST}

There are no conflicts of interest for anyone.

\section{DEDICATION}

Give my work humility to the faculty of pharmacy and professors specialized in the fields of chemistry and biology.

\section{FUNDING OF RESEARCH}

The research was funded by the researchers himself.

\section{AUTHOR'S CONTRIBUTIONS}

This research was done individually in the laboratories of the College of Agriculture, University of Basrah. This research was completed over a period of 3 months with serious and continuous work, and therefore, excellent results were obtained in finding an easy and sensitive way to estimate the $\mathrm{O}$-vertamide compound in extract from pomegranate husks and study of its biological effect.

Ethics: We undertake to address any ethical or health issues that may arise after the publication of this manuscript.

\section{REFERENCES}

1. Kobayashi H. Structural and functional analysis of the serine protease from Aeromonas sobria. Yakugaku Zasshi 2011;131:1781-6.

2. Govaris A, Botsoglou E, Moulas A, Botsoglou N. Effect of dietary olive leaves and rosemary on microbial growth and lipid oxidation of turkey breast during refrigerated storage. S Afr J Anim Sci 2010;40:145-55.

3. Melouane B, Amhamdi H, Wathelet JP, Ankit M, Khedid K, El Bachiri A. Chemical composition and antimicrobial effect of essential oil of thyme (Thymus vulgaris) from Eastern Morocco. Int J Agric Biol 2009;11:205-8.

4. Merino S, Camprubi S, Tomas JM. Effect of growth temperature on outer membrane components and virulence of Aeromonas hydrophila strains of serotype
O: 34. Infect Immun 1992;60:4343-9.

5. Seshadri R, Joseph SW, Chopra AK, Sha J, Shaw J, Graf J, et al. Genome sequence of Aeromonas hydrophila ATCC 7966T: Jack of all trades. J Bacteriol 2006;188:8272-82.

6. Jayavignesh V, Kannan KS, Bhat AD. Biochemical characterization and cytotoxicity of the Aeromonas hydrophila isolated from catfish. Arch Appl Sci Res 2011;3:85-93.

7. AL-Hashimia AG, AL-Salman HN, Al-Jadaan SA. GC-mass analysis and estimation of pomegranate husks extracts and the biological efficacy of compound tributyl acetyl citrate as one of the extract against food fungi. Orient J Chem 2018;34:2089-97.

8. Al-Salman HN, Jasim EQ. Analytical methods for diagnosis a mixture of narcotic substances in seized materials. Int J Green Pharm 2018;12:216-26.

9. Abbott SL, Cheung WK, Janda JM. The genus Aeromonas: Biochemical characteristics, atypical reactions, and phenotypic identification schemes. J Clin Microbiol 2003;41:2348-57.

10. Citarasu T, Dhas A, Velmurugan K, Thanga V, Kumaran V. Isolation of Aeromonas hydrophila from infected ornamental fish hatchery during massive disease outbreak. Int J Res 2011;2:37-41.

11. Lukkana M, Wongtavatchai J, Chuanchuen R. Class 1 integrons in Aeromonas hydrophila isolates from farmed Nile tilapia (Oreochromis nilotica). J Vet Med Sci 2012;74:435-40.

12. Shak JR, Whitaker JA, Ribner BS, Burd EM. Aminoglycoside-resistant Aeromonas hydrophila as part of a polymicrobial infection following a traumatic fall into freshwater. J Clin Microbiol 2011;49:1169-70.

13. Fabio A, Corona A, Forte E, Quaglio P. Inhibitory activity of spices and essential oils on psychrotrophic bacteria. New Microbiol 2003;26:115-20.

14. Matsuzaki K. Why and how are peptide-lipid interactions utilized for self-defense? Magainins and tachyplesins as archetypes. Biochim Biophys Acta 1999;1462:1-10.

15. González MJ, Marioli JM. Antibacterial activity of water extracts and essential oils of various aromatic plants against Paenibacillus larvae, the causative agent of American foulbrood. J Invertebr Pathol 2010;104:209-13.

16. Rota MC, Herrera A, Martínez RM, Sotomayor JA, Jordán MJ. Antimicrobial activity and chemical composition of Thymus vulgaris, Thymus zygis and Thymus hyemalis essential oils. Food Control 2008;19:681-7.

17. Bajpai VK, Rahman A, Kang SC. Chemical composition and inhibitory parameters of essential oil and extracts of Nandina domestica Thunb. To control food-borne pathogenic and spoilage bacteria. Int J Food Microbiol 2008; 125:117-22.

18. Amensour M, Bouhdid S, Fernández-LópezJ, Idaomar M, Senhaji NS, Abrini J. Antibacterial activity of extracts of Myrtus communis against food-borne pathogenic and spoilage bacteria. Int J Food 2010;13:1215-24. 
19. Alishahi M, Ghorbanpoor M, Najafzadeh $H$, Pashmforoosh M. Antibacterial effects of some medical plant extracts on Aeromonas hydrophila, Yersinia ruckeri and Streptococcus iniae. Sci Res Iran Vet J 2010;2:21-30.

20. Al-Salman HN. Analysis methods and qualitative diagnosis chromatographic for mixture of narcotic substances in seized materials. Eur J Sci Res 2017;147:403-11.

21. Ghareeb M, Akhlaghi F. Alternative matrices for therapeutic drug monitoring of immunosuppressive agents using LC-MS/MS. Bioanalysis 2015;7:1037-58.

22. Mika A, Stepnowski P. Current methods of the analysis of immunosuppressive agents in clinical materials: A review. J Pharm Biomed Anal 2016;127:207-31.

23. Juliano LM, Griffiths RR. A critical review of caffeine withdrawal: Empirical validation of symptoms and signs, incidence, severity, and associated features. Psychopharmacology (Berl) 2004;176:1-29.

24. Liu Z, Brady A, Young A, Rasimick B, Chen K, Zhou $\mathrm{C}$, et al. Length effects in antimicrobial peptides of the (RW)n series. Antimicrob Agents Chemother 2007;51:597-603.

25. Mohammed AM, Ihmood KJ, Abdullmajeed KA. Synthesis characterization and biological activity evaluation of some new azo derivatives from 2- amino benzothiazole and their derivatives. Kirkuk Univ J Sci Stud 2018;13:212-27.

26. Manolov I, Maichle-Moessmer C, Nicolova I, Danchev N. Synthesis and anticoagulant activities of substituted 2,4-diketochromans, biscoumarins, and chromanocoumarins. Arch Pharm Chem Life Sci 2006;339:319-26.

27. Popescu I, Lupea AX, Hadaruga D, Hadaruga N, Borozan A, Ienascu I. The IX International Symposium Young People and Multidisciplinary Research. Timisoara: Electronic Publication; 2004. p. 112.

28. Jung BO, Kim CH, Choi KS, Lee YM, Kim JJ. Preparation of amphiphilic chitosan and their antimicrobial activities. J Appl Polym Sci 1999;72:1713-9.

29. Kim KW, Thomas RL, Lee C, Park HJ. Antimicrobial activity of native chitosan, degraded chitosan, and O-carboxymethylated chitosan. J Food Prot 2003;66:1495-8.

30. Omar SH. Oleuropein in olive and its pharmacological effects. Sci Pharm 2010;78:133-54.

31. Al-Sowdani KH, Al-Salman HN. Determination of extracted methamphetamine from hashish narcotic plant by home-made ion chromatography system. Int J Adv Res 2015;3:723-30.

32. Gunn JS, Lim KB, Krueger J, Kim K, Guo L, Hackett M, et al. PmrA-pmrB-regulated genes necessary for 4-aminoarabinose lipid A modification and polymyxin resistance. Mol Microbiol 1998;27:1171-82.

33. Shai Y. Mechanism of the binding, insertion and destabilization of phospholipid bilayer membranes by alpha-helical antimicrobial and cell non-selective membrane-lytic peptides. Biochim Biophys Acta 1999;1462:55-70.

34. Devendra SN, Goutam K, Mahender S, Navneet S. Antibacterial activity of benzimidazole derivatives: A mini review. Res Rev J Chem 2017;6:17-29.

35. Mahfuzul Hoque MD, Bari ML, Inatsu Y, Juneja VK, Kawamoto S. Antibacterial activity of guava (Psidium guajava L.) and neem (Azadirachta indica A. Juss.) extracts against foodborne pathogens and spoilage bacteria. Foodborne Pathog Dis 2007;4:481-8.

36. Dicko MH, Karou D, Simpore J, Traore AS. Antioxidant and antibacterial activities of polyphenols from ethnomedicinal plants of Burkina Faso. Afr J Biotechnol 2005;4:823-8.

37. Zhang SL, Damu GL, Zhang L, Geng RX, Zhou CH. Synthesis and biological evaluation of novel benzimidazole derivatives and their binding behavior with bovine serum albumin. Eur J Med Chem 2012;55:164-75.

38. Cushnie TP, Lamb AJ. Antimicrobial activity of flavonoids. Int J Antimicrob Agents 2005;26:343-56.

39. Jianu C, Misca C, Pop G, Rusu LC, Ardelean L, Gruia AT. Chemical composition and antimicrobial activity of essential oils obtained from dill (Anethum graveolens L.) grown in Western Romania. Rev Chim 2012;63:641-5.

40. Belaj A, Satovic Z, Rallo L, Trujillo I. Genetic diversity and relationships in olive (Olea europaea L.) germplasm collections as determined by randomly amplified polymorphic DNA. Theor Appl Genet 2002;105:638-44.

41. Toncer O, Basbag S, Karaman S, Diraz E, Basbag M. Chemical composition of the essential oils of some Achillea species growing wild in Turkey. Int J Agric Biol 2010;12:527-30.

42. Asif HM, Akram M, Uddin SH, Hasan ZU, Sami A, Iqbal A. Myrtus communis Linn. (Pharmacological effect). J Med Plants Res 2011;5:6257.

43. Bravo L, Morier L, Castañeda N, Ramírez M, Silva M, Castro-Escarpulli G, et al. Aeromonas: An emerging pathogen associated with extraintestinal infection in Cuba. Rev Cubana Med Trop 2003;55:208-9.

44. Wang L, Weller CL. Recent advances in extraction of nutraceuticals from plants. Trends Food Sci Technol 2006; 17:300-12.

Source of Support: Nil. Conflict of Interest: None declared. 